\title{
Effects of oxytocin on the bovine corpus luteum of early pregnancy
}

\author{
G. J. S. Tan, R. Tweedale and J. S. G. Biggs \\ Department of Obstetrics and Gynaecology, University of Queensland, Royal Brisbane Hospital, \\ Brisbane 4029, Australia
}

\begin{abstract}
Summary. Oxytocin, at concentrations of 4 and $40 \mathrm{mi} . \mathrm{u} . / \mathrm{ml}$, significantly enhanced progesterone production by dispersed bovine luteal cells $(0 \cdot 5-4$ months of gestation) after incubation for $3 \mathrm{~h}$. The luteotrophic effect of $4 \mathrm{mi}$.u. oxytocin $/ \mathrm{ml} \mathrm{was}$ comparable to that of $10 \mathrm{i} . \mathrm{u} . \mathrm{hCG} / \mathrm{ml}$. Higher oxytocin concentration $(800 \mathrm{mi} . \mathrm{u} . / \mathrm{ml})$ markedly inhibited the response of the luteal cells to hCG and may be inhibitory to basal progesterone production. These data provide evidence for an effect of oxytocin on the bovine corpus luteum of early pregnancy.
\end{abstract}

\section{Introduction}

There is evidence that oxytocin may be involved in the regulation of the oestrous cycle in both the sheep and the cow. Exogenous administration of oxytocin to heifers shortens the duration of the oestrous cycle (Hansel \& Wagner, 1960) while in the sheep immunization against oxytocin prolongs it (Flint, Mitchell \& Sheldrick, 1979), both observations indicating a role of oxytocin in luteolysis.

Oxytocin probably acts at the uterus to stimulate the release of prostaglandin (PG) F-2a which in turn brings about the demise of the corpus luteum. In-vitro studies have shown that oxytocin stimulates the release of PGF- $2 \alpha$ from uterine tissue (Roberts, McCracken, Gavagan \& Soloff, 1976), while in-vivo experiments have demonstrated a temporal relationship between plasma levels of oxytocin-associated neurophysin I/II and the prostaglandin F metabolite (13,14-dihydro-15-ketoprostaglandin F) at the end of the oestrous cycle (Fairclough et al., 1980). The luteolytic role of prostaglandins has been repeatedly shown (Horton \& Poyser, 1977; Fairclough, Smith \& McGowan, 1981).

The present study was undertaken to examine a possible direct effect of oxytocin on the bovine corpus luteum, using dispersed luteal cells prepared from corpora lutea of early pregnancy.

\section{Materials and Methods}

\section{Materials}

Collagenase (Worthington Type I, $213 \mathrm{U} / \mathrm{mg}$ ) was purchased from Millipore Corporation (Freehold, New Jersey, U.S.A.). Soybean trypsin inhibitor was purchased from CalbiochemBehring Corp. (La Jolla, California, U.S.A.). Deoxyribonuclease I (3235 U/mg) was obtained from Sigma Chemical Company (St Louis, Missouri, U.S.A.). Kanamycin $(5 \mathrm{mg} / \mathrm{ml})$ and fungizone $(250 \mu \mathrm{g} / \mathrm{ml})$ were obtained from Flow Laboratories (Sydney, Australia). Ham's F 10 
medium was obtained from M. A. Bioproducts (Walkersville, Maryland, U.S.A.). Human chorionic gonadotrophin (hCG, $500 \mathrm{i} . \mathrm{u} . / \mathrm{ml}$ ) was obtained from Organon (Aus.) Pty Ltd (Sydney), and synthetic oxytocin (Syntocinon, 10 i.u./ml) from Sandoz (Aus.) Pty Ltd (Sydney).

\section{Animals}

Corpora lutea were obtained from pregnant cows at the time of slaughter at the abattoir. The gestational ages were determined from fetal crown-rump lengths (Kristoffersen, 1960) and all pregnancies were of less than 4 months' duration.

\section{Preparation of luteal cells}

Isolated luteal cells were prepared by a modification of the procedure of Thibier, El-Hassan, Clark, LeMaire \& Marsh (1980). Corpora lutea were transferred to the laboratory in cold Ham's F 10 medium containing 20 mm-Hepes buffer and processed immediately. They were sliced, minced and washed three times with the same medium. The minced tissues were then digested in Ham's F $10-$ Hepes medium containing $0.2 \%$ collagenase, $0.05 \%$ trypsin inhibitor, $0.2 \%$ bovine serum albumin (BSA), $1 \%$ fungizone, $1 \%$ kanamycin and $4 \mu \mathrm{g} \mathrm{DNAse} / \mathrm{ml}$ at a concentration of $100 \mathrm{mg}$ tissue $/ \mathrm{ml}$ digestion medium. Digestion was carried out under an atmosphere of $95 \% \mathrm{O}_{2}-5 \% \mathrm{CO}_{2}$ at $37^{\circ} \mathrm{C}$ with constant stirring. After $1 \mathrm{~h}$, the supernatant was collected. The remaining tissue fragments were re-digested for $1 \mathrm{~h}$ more and the supernatant again collected. Luteal cells were obtained from each supernatant by filtration through a $105 \mu \mathrm{m}$ nylon filament mesh followed by centrifugation of the filtrate at $100 \mathrm{~g}$ for $5 \mathrm{~min}$. The cell pellet thus obtained was washed twice and resuspended in Ham's F10-Hepes medium containing $0.2 \%$ BSA, $1 \%$ fungizone and $1 \%$ kanamycin (the incubation medium). Cell suspensions from the two supernatants were pooled and refiltered through the nylon mesh before making up to the final volume for incubation studies. The cells were counted on a haemocytometer and the viability, as assessed by trypan blue exclusion (Tennant, 1964), was over $70 \%$. The cell suspension consisted of single luteal cells (10-40 $\mu \mathrm{m}$ diameter), cells in clumps and red blood cells.

\section{Incubation studies}

Approximately $10^{5}$ cells were incubated with constant shaking in a final volume of $0.5 \mathrm{ml}$ incubation medium under an atmosphere of $95 \% \mathrm{O}_{2}-5 \% \mathrm{CO}_{2}$ at $37^{\circ} \mathrm{C}$. The test substances were added at a volume of $20 \mu \mathrm{l}$. Both hCG and oxytocin were diluted with Ham's F10 medium. The incubations were terminated by freezing the samples in solid $\mathrm{CO}_{2}$.

\section{Radioimmunoassay of progesterone}

Progesterone was assayed by the method of Abraham, Swerdloff, Tulchinsky \& Odell (1971) with minor modifications. The samples (cells and medium) were extracted with diethyl ether before assay. Progesterone antiserum (No. 334) was kindly supplied by Dr R. I. Cox, C.S.I.R.O. Division of Animal Production (Prospect, Australia). Steroids showing major cross-reactivity with the antiserum are $11 \beta$-hydroxyprogesterone $(27 \%)$, corticosterone $(5.8 \%)$ and $5 \beta$-pregnane-3,20-dione $(1.4 \%)$. The sensitivity of the standard curve was $9 \mathrm{pg}$ and the average blank value did not exceed this. Mean ( \pm s.d.) assay value for progesterone added to the culture medium at a concentration of $10 \mathrm{ng} / \mathrm{ml}$ was $10.6 \pm 0.6 \mathrm{ng} / \mathrm{ml}(n=18)$. Inter- and intra-assay coefficients of variation were $7 \cdot 2 \%(n=25)$ and $5 \cdot 3 \%(n=18)$ respectively.

Progesterone production was all normalized to $1 \times 10^{5}$ cells/incubation, and the data were statistically analysed by paired comparison using Student's $t$ test $(P$ values $>0.01$ were not considered significant). 


\section{Results}

As shown in Table 1, net progesterone production occurred in all the samples, except for one corpus luteum for which there was no significant steroid production. Addition of oxytocin, at concentrations of 4 and $40 \mathrm{mi} . \mathrm{u} . / \mathrm{ml}$, significantly enhanced progesterone production by the luteal cells after $3 \mathrm{~h}$ of incubation. A higher oxytocin concentration $(800 \mathrm{~m} . \mathrm{i} . \mathrm{u} . / \mathrm{ml})$ either inhibited the basal progesterone production or had little effect on it. There was no effect on the cell numbers or viability at this high oxytocin concentration, suggesting that the action of this hormone is at the luteal steroidogenic pathway rather than due to a toxic effect. Addition of hCG $(10 \mathrm{i} . \mathrm{u} . / \mathrm{ml})$ significantly increased progesterone production in all the incubated samples. This hCG-induced progesterone production was inhibited by $800 \mathrm{mi}$.u. oxytocin/ml but not by the lower concentrations, although in one luteal cell preparation, inhibition was apparent at 400 mi.u. oxytocin $/ \mathrm{ml}$.

Table 1. Effects of oxytocin on progesterone production by dispersed luteal cells of early bovine pregnancies

\begin{tabular}{|c|c|c|c|c|}
\hline \multirow[b]{2}{*}{ Experiment } & \multicolumn{4}{|c|}{ Progesterone content (ng/10 cells) } \\
\hline & B 1 & B2 & B3 & B4 \\
\hline $\begin{array}{l}\text { Stage of pregnancy } \\
\text { (months) }\end{array}$ & $0 \cdot 5-1$ & $1-2$ & $2-3$ & $3-4$ \\
\hline Unincubated control & $5 \cdot 6 \pm 0.8$ & $25 \cdot 7 \pm 1 \cdot 5$ & $5 \cdot 5 \pm 0.6$ & $8 \cdot 6 \pm 1.0$ \\
\hline $\begin{array}{l}\text { Incubated control } \\
\text { Oxytocin (mi.u./ml) }\end{array}$ & $8 \cdot 5 \pm 0.5^{a}$ & $32 \cdot 6 \pm 3 \cdot 1^{\mathrm{a}}$ & $9.9 \pm 0.5^{b}$ & $11 \cdot 6 \pm 2 \cdot 4$ \\
\hline 4 & - & $84 \cdot 0 \pm 15 \cdot 1^{d}$ & $24 \cdot 5 \pm 2 \cdot 4^{\mathrm{d}}$ & $109 \cdot 7 \pm 14 \cdot 1^{d}$ \\
\hline 40 & $10 \cdot 3 \pm 0.8^{c}$ & $89 \cdot 8 \pm 10 \cdot 7^{d}$ & $17 \cdot 8 \pm 3 \cdot 0^{\mathfrak{c}}$ & $78 \cdot 1 \pm 14 \cdot 6^{d}$ \\
\hline 400 & $7 \cdot 1 \pm 0 \cdot 3^{\mathrm{c}}$ & $38 \cdot 1 \pm 2 \cdot 3$ & $9.4 \pm 0.5$ & $18 \cdot 5 \pm 5.4$ \\
\hline 800 & $6 \cdot 0 \pm 0 \cdot 3^{d}$ & $30 \cdot 2 \pm 3 \cdot 3$ & $7.7 \pm 0.9^{c}$ & $13 \cdot 1 \pm 3 \cdot 7$ \\
\hline $\begin{array}{l}\text { hCG }(10 \text { i.u. } / \mathrm{ml}) \\
\text { hCG + oxytocin (mi.u./ml) }\end{array}$ & $15 \cdot 4 \pm 3 \cdot 7^{\mathrm{c}}$ & $109 \cdot 0 \pm 14 \cdot 9^{d}$ & $30 \cdot 0 \pm 4 \cdot 2^{c}$ & $108 \cdot 5 \pm 19 \cdot 1^{d}$ \\
\hline 4 & - & $105 \cdot 2 \pm 8 \cdot 0$ & $27 \cdot 0 \pm 3.8$ & $116 \cdot 0 \pm 15 \cdot 6$ \\
\hline 40 & $12 \cdot 3 \pm 0.5$ & $121 \cdot 2 \pm 19 \cdot 5$ & $21 \cdot 5 \pm 3 \cdot 8$ & $90 \cdot 2 \pm 15 \cdot 9$ \\
\hline 400 & $10 \cdot 4 \pm 0.5$ & $109.0 \pm 11.9$ & $19 \cdot 2 \pm 3 \cdot 2^{e}$ & $96.1 \pm 11.6$ \\
\hline 800 & $8.5 \pm 0.8^{e}$ & $70.6 \pm 4.8^{e}$ & $13 \cdot 5 \pm 2 \cdot 1^{f}$ & $48 \cdot 3 \pm 15 \cdot 2^{\mathrm{e}}$ \\
\hline
\end{tabular}

Luteal cells were incubated for $3 \mathrm{~h}$ in Ham's F10 medium with various test substances in $95 \%$ $\mathrm{O}_{2}-5 \% \mathrm{CO}_{2}$ at $37^{\circ} \mathrm{C}$. All values represent the mean \pm s.d. of quadruplicate incubates. ${ }^{\mathrm{a} P}<0.01$, ${ }^{b} P<0.001$, compared with unincubated control; ${ }^{c} P<0.01$, ${ }^{\mathrm{d}} P<0.001$, compared with incubated control; ${ }^{\mathrm{e} P}<0.01,{ }^{\mathrm{f}} P<0.001$, compared with hCG.

\section{Discussion}

In non-pregnant cows and sheep, there is evidence that PGF-2 $\alpha$ of uterine origin is the physiological luteolysin (Fairclough et al., 1981). Towards the end of the oestrous cycle, therefore, increased oxytocin secretion is thought to trigger the production of uterine PGF- $2 \alpha$ which then acts locally on the ipsilateral corpus luteum to bring about its regression (Fairclough et al., 1980). However, if pregnancy intervenes, the corpus luteum does not regress because progesterone from the corpus luteum is essential for the maintenance of pregnancy. The mechanism by which the corpus luteum is maintained is not well defined. Recent studies suggest that the embryo may inhibit the secretion of maternal oxytocin, thereby removing the stimulus for the production of PGF-2 $\alpha$ in the uterus (Moore et al., 1980).

The results of the present study show that oxytocin can influence the corpus luteum of early 
pregnancy directly, thus providing another site of oxytocin action in the control of luteal function besides the uterus. The results also indicate that oxytocin may be either luteotrophic or luteolytic depending on its concentration. At a concentration of $4 \mathrm{mi} . \mathrm{u} . / \mathrm{ml}$, oxytocin significantly stimulated progesterone production by the luteal cells. The increase in progesterone production was comparable to that induced by $10 \mathrm{i} . \mathrm{u}$. hCG $/ \mathrm{ml}$, a dosage which is maximal for progesterone production by dispersed luteal cells prepared from rat and human corpora lutea (unpublished observation). A higher oxytocin concentration $(800 \mathrm{mi} . \mathrm{u} . / \mathrm{ml})$ markedly inhibited the response of the luteal cells to hCG and may be inhibitory to the basal steroid production. These inhibitory actions of oxytocin may reflect functional luteolysis or desensitization in vitro and remain to be investigated. In view of these effects of oxytocin, a similar mode of action may be operative in vivo whereby oxytocin is luteotrophic in low concentration and luteolytic at a higher concentration. If this is found to be true, the role of embryonic suppression of maternal oxytocin secretion may be extended to include not only inhibition of uterine prostaglandin production, but also a direct luteotrophic support by the low oxytocin levels. The luteolytic action of high oxytocin concentrations may, however, be more important in the control of the oestrous cycle, if oxytocin similarly affects the corpus luteum of the non-pregnant cow. Thus, at the end of the oestrous cycle, increased oxytocin secretion may bring about the demise of the corpus luteum by its action on the uterus and the ovary.

We thank the University of Queensland for a scholarship (G.J.S.T.).

\section{References}

Abraham, G.E., Swerdloff, R., Tulchinsky, D. \& Odell, W.D. (1971) Radioimmunoassay of plasma progesterone. J. clin. Endocr. Metab. 32, 619-624.

Fairclough, R.J., Moore, L.G., McGowan, L.T., Peterson, A.J., Smith, J.F., Tervit, H.R. \& Watkins, W.B. (1980) Temporal relationship between plasma concentrations of 13,14-dihydro-15-keto-prostaglandin $F$ and neurophysin I/II around luteolysis in sheep. Prostaglandins 20, 119-208.

Fairclough, R.J., Smith, J.F. \& McGowan, L.T. (1981) Prolongation of the oestrous cycle in cows and ewes after passive immunization with PGF antibodies. $J$. Reprod. Fert. 62, 213-219.

Flint, A.P.F., Mitchell, M.D. \& Sheldrick, E.L. (1979) Delayed luteal regression in ewes immunized against oxytocin. J. Physiol., Lond. 269, 85-86.

Hansel, W. \& Wagner, W.C. (1960) Luteal inhibition in the bovine as a result of oxytocin injections, uterine dilatation, and intrauterine infusions of seminal and preputial fluids. J. Dairy Sci. 43, 796-805.

Horton, E.W. \& Poyser, N.L. (1977) Uterine luteolytic hormone: a physiological role for prostaglandin $\mathrm{F}_{2} \mathrm{\alpha}$. Physiol. Rev. 56, 595-651.
Kristoffersen, J. (1960) Gestogens in corpus luteum of cattle. Acta endocr., Copenh. 33, 417-427.

Moore, L.G., Fairclough, R.J., Peterson, A.J., Tervit, H.R., Havik, P.G., Smith, J.F. \& Watkins, W.B. (1980) Neurophysin I/II levels during early pregnancy in the ewe. Proc. Endocr. Soc. Austr. 23, S7, Abstr.

Roberts, J.S., McCracken, J.A., Gavagan, J.E. \& Soloff, M.S. (1976) Oxytocin-stimulated release of prostaglandin $\mathrm{F}_{2} \alpha$ from ovine endometrium in vitro: correlation with estrous cycle and oxytocin-receptor binding. Endocrinology 99, 1107-1114.

Tennant, J.R. (1964) Evaluation of the trypan blue techniques for determination of cell viability. Transplantation 2, 685-694.

Thibier, M., El-Hassan, N., Clark, M.R., LeMaire, W.J. \& Marsh, J.M. (1980) Inhibition by estradiol of human chorionic gonadotropin-induced progesterone accumulation in isolated human luteal cells: lack of mediation by prostaglandin F. J. clin. Endocr. Metab. 50, 590-592.

Received 8 October 1981 